\title{
Analysis Of Community Satisfaction Index (SMI) Survey On One Door Integrated Services (PTSP)
}

\author{
Fina Nurmita \\ Kantor Wilayah Kementerian Agama Provinsi Bengkulu \\ Email: finanurmita91@gmail.com
}

Received: 13 August 2021; Revised: 02 October 2021; Accepted: 14 December 2021

DOI: http://dx.doi.org/10.37905/aksara.8.1.395-400.2022

\begin{abstract}
This study aims to assess the index of community satisfaction with one-stop integrated services at the Regional Office of the Ministry of Religion of Bengkulu Province. The unit of analysis is the community that uses services such as legalizing marriage books, legalizing diplomas and others. The results of the descriptive analysis show that the Community Satisfaction Index of service users such as legalizing marriage books, legalizing diplomas and others is 3.56 with very good criteria. The results of the analysis of each IKM parameter can be seen as follows; (1). Requirements is Good with a score of 3.48; (2) Systems, mechanisms and procedures is Good with a score of 3.47; (3) Completion Time is Good with a score of 3.35; (4) Cost/Tariff is Very Good with a score of 3.98; (5) Product specification type of service is Good with a score of 3.38; (6) Excellent implementing competence is very good with a score of 3.53; (7) The behavior of the implementer is very good with a score of 3.54; (8) Handling complaints, suggestions and inputs is Good with a score of 3.44; (9) Facilities and Infrastructure is Very Good with a score of 3.82. Thus, the index value is 3.56, then the IKM value after conversion (Index Value $\mathrm{x}$ Basic Value), namely; 3.56 x $25=88.9$.
\end{abstract}

Keywords: Survey, Index, Community Satisfaction, Service

\section{PRELIMINARY}

The government has a very high responsibility regarding the satisfaction of services provided to the community. Even at the central government level to the regional government. The quality of service must be maintained for the community, because according to Lovelock as quoted by (Tjiptono \& Chandra, 2005) states that service quality is an expected level of excellence and control over that level of excellence to meet customer expectations. According to Ratminto \& Winarsih, 2005 Public service is an activity that is invisible (cannot be touched) that occurs as a result of interactions between consumers and employees or other things provided by the company/state.

Public services carried out by the Regional Office of the Ministry of Religion of Bengkulu Province are currently held through the One Stop Integrated Service (PTSP). Public services organized by the Regional Office of the Ministry of Religion of Bengkulu Province through PTSP totaling 28 services, all of which are a combination of the types of services in each Sector/Sub-Division/Business. One of the efforts that must be made in improving public services at PTSP Regional Office of the Ministry of Religion of Bengkulu Province is to conduct a Community Satisfaction Survey to service users by measuring the level of satisfaction of service users. With the implementation of the Community Satisfaction Survey on services at the PTSP Regional Office of the Ministry of Religion of Bengkulu Province, it is expected to be able to measure the level of community satisfaction with the services that have been provided. It is hoped that this Community Satisfaction Survey will be one step in 
improving the quality of public service delivery at the PTSP Regional Office of the Ministry of Religion of Bengkulu Province. This survey is comprehensive and the results of the survey analysis are used to evaluate community satisfaction with the services provided. In addition, the survey results are used as material for policy on public services and to see trends in public services that have been provided by the PTSP Regional Office of the Ministry of Religion of Bengkulu Province to the community as well as the performance of public service providers.

\section{METHOD}

To conduct periodic surveys using a qualitative method approach with measurements using a Likert Scale. The Likert scale is a psychometric scale commonly used in questionnaires, and is the most widely used scale in survey research. This method was developed by Rensis Likert. Likert scale is a scale that can be used to measure attitudes, opinions, and perceptions of a person or group of people towards a type of public service. On a Likert scale, respondents were asked to determine their level of agreement with a statement by choosing one of the available options. The technique of collecting data in this research is by distributing questionnaires/questionnaires to the people in Bengkulu Province who are the population of this study. Population is a generalization area consisting of subjects/objects that have certain quantities or characteristics (Arikunto, 2009).

The Community Satisfaction Survey at the PTSP Regional Office of the Ministry of Religion of Bengkulu Province was carried out by the Implementation Team of the Community Satisfaction Survey which had been appointed and determined by the Decree of the Head of the Regional Office of the Ministry of Religion of Bengkulu Province Number 125 of 2021 concerning the Implementation Team of the Community Satisfaction Survey on One Stop Integrated Services (PTSP).) Regional Office of the Ministry of Religion of Bengkulu Province.

The Community Satisfaction Survey at the PTSP Regional Office of the Ministry of Religion of Bengkulu Province is carried out by the Implementation Team of the Community Satisfaction Survey which has been appointed and determined by the Decree of the Head of the Regional Office of the Ministry of Religion of Bengkulu Province Number 125 of 2021 concerning the Implementation Team of the Community Satisfaction Survey on One Stop Integrated Services (PTSP). Regional Office of the Ministry of Religion of Bengkulu Province.

The stages of implementing this Community Satisfaction Survey include the following steps:

Prepare survey instruments;

The Community Satisfaction Survey Instrument was prepared based on the Regulation of the Minister for Empowerment of State Apparatus and Bureaucratic Reform Number 14 of 2017 concerning Guidelines for Compilation of Community Satisfaction Surveys for Public Service Providers. The Instrument of Community Satisfaction Survey is in the form of a Questionnaire with multiple choice answers based on a Likert Scale. The form of the answer choices for the Questionnaire is qualitative to reflect the level of service quality. The level of service quality starts from very good/satisfied to not good/satisfied. The answers are divided into 4 (four) categories, namely:

1) Bad, given a perception value of 1 ; 
2) Not good, given a perception value of 2 ;

3) Good, rated 3;

4) Very good, given a perception rating of 4 .

Determining the amount and technique of sampling;

Determination of the number of respondents is based on the sample table from Krejcie and Morgan (Appendix II Regulation of the Minister for Empowerment of State Apparatus and Bureaucratic Reform Number 14 of 2017 concerning Guidelines for Compiling a Public Satisfaction Survey for Public Service Providers). In 2020, the total population $(\mathrm{N})$ at the PTSP Regional Office of the Ministry of Religion of Bengkulu Province is 820 , with the following details:

Table 1 Details of Service Types at PTSP

\begin{tabular}{lll}
\hline No & Type of Service & Total \\
\hline $\mathbf{1}$ & Legalization of Marriage Book & 735 \\
\hline $\mathbf{2}$ & Legalization of Diplomas & 31 \\
\hline $\mathbf{3}$ & Others & 54 \\
\hline Total & & 820
\end{tabular}

Based on the Morgan and Krejcie Sample Tables in Appendix II of the Regulation of the Minister of State Apparatus Empowerment and Bureaucratic Reform Number 14 of 2017 concerning Guidelines for Compiling a Community Satisfaction Survey for Public Service Providers, the number of samples for the Community Satisfaction Survey in 2021 is 260 samples, with details of each - 130 samples each for survey periods I and II. The quality of service based on the value of the Community Satisfaction Index in accordance with Appendix III of the Regulation of the Minister of Empowerment of State Apparatus and Bureaucratic Reform Number 14 of 2017 concerning Guidelines for Compiling a Community Satisfaction Survey for Public Service Provider Units, is as follows:

\section{Survey Techniques}

$$
\begin{aligned}
& >\text { A (Very Good) } \quad: \quad 88,31-100 \\
& >\mathrm{B} \text { (Good) : 76,61-88,30 } \\
& >\mathrm{C}(\text { Not Good }) \quad: \quad 65,00-76,60 \\
& >\mathrm{D}(\mathrm{Bad}) \quad: 25,00-64,99
\end{aligned}
$$

The implementation of the Community Satisfaction Survey at the PTSP Regional Office of the Ministry of Religion of Bengkulu Province uses a direct survey technique, where respondents are asked to fill out a questionnaire that has been prepared by the officer. After completing the assessment, the questionnaire was collected again until the number of respondents met the target.

\section{RESULT AND DISCUSSION \\ Results and Processing of Data}

The public opinion data that has been included in each questionnaire is compiled by compiling respondent data which is compiled based on age group, gender, last education and main occupation. This information is to find out the respondent's profile and trends. Questionnaire data processing begins with measuring based on Likert Scale. Each question for each survey element is scored using a "weighted average" for each service element. In calculating the Community Satisfaction Survey for the service elements studied, each service element has the same weight. The following is the data for 
respondents in the first semester of the Community Satisfaction Survey at PTSP Regional Office of the Ministry of Religion of Bengkulu Province based on:

1. Gender

$$
\begin{array}{ll}
\text { Female } & : 84 \text { Orang } \\
\text { Male } & : \text { 46 Orang } \\
\text { Total } & : 130 \text { Orang }
\end{array}
$$

2. Types of Services at PTSP

$\begin{array}{lr}\text { Legalization of Marriage Book } & : 123 \text { Orang } \\ \text { Legalization of Diplomas } & : 4 \text { Orang } \\ \text { Others } & : \quad 3 \text { Orang } \\ \text { Total } & : 130 \text { Orang }\end{array}$

Each respondent has filled in an opinion about the services available at the Bengkulu Province Ministry of Religion Regional Office which consists of 9 service elements by choosing one of the four answers provided. Based on Appendix III of the Regulation of the Minister of Administrative Reform and Bureaucratic Reform Number 14 of 2017 concerning Guidelines for Compiling a Community Satisfaction Survey for Public Service Providers, the calculation results from the Community Satisfaction Survey at the Regional Office of the Ministry of Religion of Bengkulu Province can be presented in the following table:

\begin{tabular}{|c|c|c|c|c|}
\hline No & Elements of Service & $\begin{array}{l}\text { Total Perception } \\
\text { Value }\end{array}$ & $\begin{array}{l}\text { Interval } \\
\text { Value }\end{array}$ & Description \\
\hline 1 & Requirements & 453 & 3,48 & Good \\
\hline 2 & $\begin{array}{l}\text { Systems, Mechanisms and } \\
\text { Procedures }\end{array}$ & 451 & 3,47 & Good \\
\hline 3 & Completing Time & 436 & 3,35 & Good \\
\hline 4 & Fees/Tariffs & 517 & 3,98 & Very Good \\
\hline 5 & $\begin{array}{l}\text { Product Specification type of } \\
\text { service }\end{array}$ & 440 & 3,38 & Good \\
\hline 6 & Implementing competence & 459 & 3,53 & Very Good \\
\hline 7 & Implementing behavior & 460 & 3,54 & Very Good \\
\hline 8 & $\begin{array}{l}\text { Handling Complaints, } \\
\text { Suggestions and Feedback }\end{array}$ & 447 & 3,44 & Good \\
\hline 9 & Facilities and infrastructure & 497 & 3,82 & Very Good \\
\hline
\end{tabular}

Table 2 Calculation Results of the Community Satisfaction Survey at the Regional Office of the Ministry of Religion of Bengkulu Province in the first semester of 2021

To determine the Community Satisfaction Index (IKM), it is obtained by adding up the Interval Value obtained and dividing by the number of Service Elements assessed based on a predetermined Likert Scale. The IKM results obtained are converted to a base value of 25 , to facilitate interpretation in the interval of 25-100.

$I K M=\frac{\sum_{i=1}^{9} \bar{x}_{l}}{9} \times 25$ 


$$
\begin{aligned}
& =\frac{(3,48+3,47+3,35+3,98+3,38+3,53+3,54+3,44+3,82)}{9} \times 25 \\
I K M & =\frac{32}{9} \times 25=3,56 \times 25=88,9
\end{aligned}
$$

From the calculation above, the Community Satisfaction Index obtained from the results of the Community Satisfaction Survey at the Regional Office of the Ministry of Religion of Bengkulu Province which has been carried out from January to June 2021 has a value of 88.9 or with the predicate "Very Good".

\section{Analysis of Survey Result}

Based on the results of the calculations in the Appendix to the Public Satisfaction Survey Report for Semester I, the total respondents' scores from 9 questions

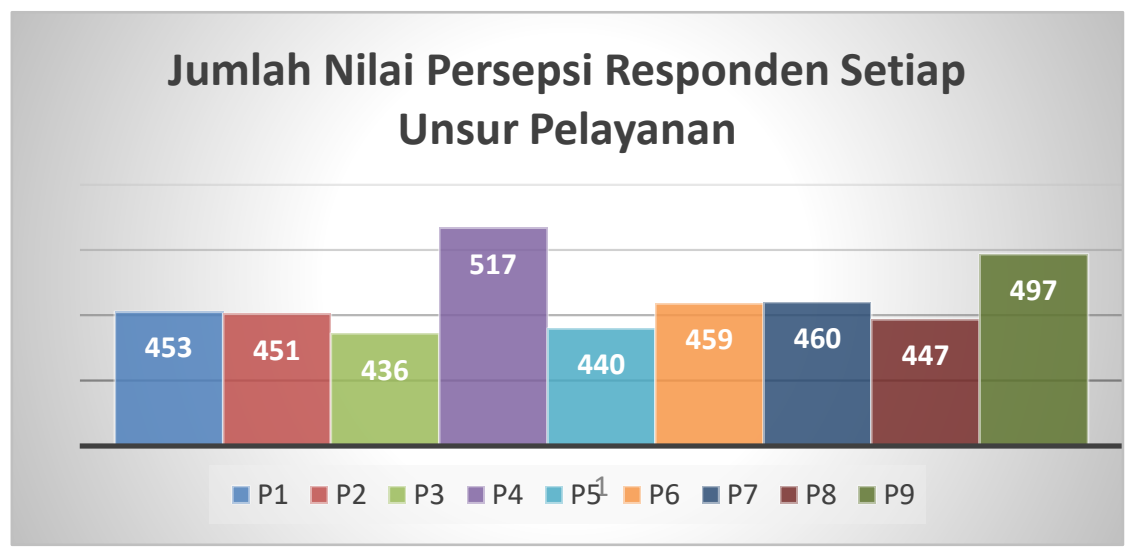

regarding service elements can be seen in the following graph:

Graph 1 Results of Respondents' Assessment of Services at the Regional Office of the Ministry of Religion of Bengkulu Province in Semester 1 of 2021

Based on the assessment of respondents in question number 4, 517 out of 130 respondents regarding fees or tariffs on services get the highest value, because in services there are no fees/tariffs charged. This is of course in accordance with the Government's program in Accelerating the Implementation of Bureaucratic Reform in terms of improving the quality of public services that are anti-gratification and extortion. While the lowest perception value is in question number 3 about service time, which is 436 of 130 respondents. The perception value that has been obtained is converted into the Interval Value (NI). The Interval (NI) value for each service element from 130 respondents can be described in the following graph:

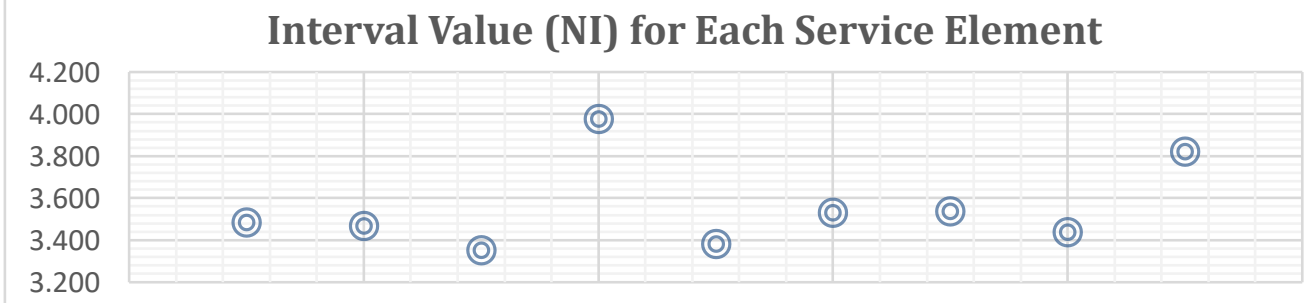

Graph 2 Respondent Interzal Values About Services ${ }^{6}$ at the Regiơnal Office of the Ministry of Religion of Bengkulu Province Semester 1 of 2021 
From graph 2 above, it can be seen that the service element number 4 regarding service fees/tariffs gets the highest perceived value and service element number 3 regarding service time gets the lowest value. However, of the 9 (nine) service elements, all of them have values with an interval of 3.0644 - 3.532 (Good) and an interval of $3.5324-4.00$ (very Good).

\section{CONCLUSION}

Based on the Regulation of the Minister for Empowerment of State Apparatus and Bureaucratic Reform Number 14 of 2017 concerning Guidelines for Compiling a Community Satisfaction Survey for Public Service Providers, every government agency that provides public services is required to carry out a Community Satisfaction Survey on a regular basis, including the Regional Office of the Ministry of Religion of Bengkulu Province. Public services at the Regional Office of the Ministry of Religion of Bengkulu Province are organized by the One Stop Service (PTSP). Therefore, the Community Satisfaction Survey on the implementation of public services was carried out at the PTSP Regional Office of the Ministry of Religion of Bengkulu Province.

Community Satisfaction Survey at PTSP Regional Office of the Ministry of Religion of Bengkulu Province, carried out periodically 6 (six) months, namely Semester I and Semester II. For Semester I, the Community Satisfaction Survey has been carried out starting from January - June 2021.

Based on the results of data processing in the previous chapter, the Community Satisfaction Index (IKM) has been obtained with a value of 88.9 or with the predicate "Very Good". This illustrates that the implementation of public services at the PTSP Regional Office of the Ministry of Religion of Bengkulu Province has been very good in accordance with the expectations to be achieved.

\section{REFERENCES}

Arikunto, S. (2009). Metodelogi Penelitian (edisi revisi). Yogyakarta: Bina Aksara.

Peraturan Menteri Pendayagunaan Aparatur Negara dan Reformasi Birokrasi Nomor 14 Tahun 2017 tentang Pedoman Penyusunan Survei Kepuasan Masyarakat Unit Penyelenggara Pelayanan Publik.

Ratminto, \& Winarsih, A. S. (2005). Manajemen Pelayanan. Yogyakarta: Pustaka Pelajar.

Tjiptono, F., \& Chandra, G. (2005). Service, Quality \& Satisfaction. Yogyakarta: Andi Offset. 